supply of convenient and cheaper apparatus for better living unless restrictive practices on the part of both employer and employee are removed. If it is largely a matter of John keeping up with Ivan, Jo and Johann in the production of better rockets and aircraft, it has not served its purpose, and may be positively harmful. The development of scientific and technical education cannot be considered in vacuo: it must become a harmonious part of the education of the whole man. W. L. SUMNer

\section{SPECIALIZED CONTRIBUTIONS TO PLANT SYSTEMATICS}

Recent Researches in Plant Taxonomy

Edited by Dr. W. B. Turrill. (Vistas in Botany, Vol. 4.) (International Series of Monographs on Pure and Applied Biology. Division: Botany, Vol. 7.) Pp. xiii +314. (London and New York: Pergamon Press, 1964.) $105 s$. net.

$7 \mathrm{HE}$ original Vistas in Botany was a volumo in honour of the bicentenary of the Royal Botanic Gardens, Kew. It appeared in 1959, and was at the same time Volume 2 in an international series of monographs on pure and applied biology. Volume 2 of Vistas in Botany was Volume 5 in this same series, and it contained reviews of topies in the genoral field of economic botany, thus acting as a useful extension of the original volume. Volume 3 was wholly physiological. Volume 4 bears the sub-title Recent Researches in Plant Taxonomy.

In view of the contents of the volume, the sub-titlo is rather misleading, for here are seven articles, essays or comprehensive reviews in which reference to recent research is mado in very varying degree. Again, the seven topics, though all in some way connected with the practice of plant taxonomy, are treated so very differently by the different authors that the volume as a whole lacks unity and it is hard to see at exactly what class of reader it is aimed. The present position in flowering plant taxonomy is better stated, and the literature as a whole better covered, in the recent work by Davis and Heywood (Principles of Angiosperm Taxonomy), so that the value of the present volume lies rather in the weight of authority with which particular authors of international renown are able to write on their own chosen topics.

The first 22 pages are occupied by an article on philosophy and classification by J. S. L. Gilmour and S. M. Walters. In this perspicacious and scholarly article thore is plonty of food for thought, but its content does not rango far boyond what may bo found in earlier contributions by one or other of those authors. The second chapter, of similar length, is that of Prof. G. Erdtman on palynology. Its effect is to leave one conscious of the almost excessively detailed examination to which pollen grains have been exposed in recent years. While such items as the tables on pp. 28 and 29 afford a useful summary of information, the figure on p. 31 will incline most botanists to leave pollen grains strictly to the specialists. For the few, the minute dotail will provide a fascinating challenge, and they will be attracted both by Prof. Erdtman's clear exposition and by the technical brilliance of his illustrations.

Embryology in relation to taxonomy, by Prof. P. Maheshwari, occupies $\mathbf{4 3}$ pages and is an oxcellent summary of a subject which does not always receive the attention it deserves from taxonomists. This chapter is superbly illustrated and concludes with a bibliography of 167 reforences. These features, together with the clear presentation of the selected facts, make it a most valuable part of the book.

The next 87 pages are occupied by what is not only by far the longest chapter in the book but also the one that is, both from the technical and linguistic points of view, the most difficult. One feels that "Cytologie, Taxonomie, und Evolution bei Samenpflanzen", by Dr. F. Ehrendorfer, will appeal only to comparative specialists already well acquainted with this subject and anxious to read Dr. Ehrendorfer's authoritative views on it. The 21 figures are not uniformly easy for a student to grasp, but the bibliography of 346 titles should be useful.

There follow two chapters by the late Dr. W. B. Turrill, one of 37 pages on "Plant Taxonomy, Phytogeography and Plant Ecology", the other, of 13 pages only, on "Floras". Both suffer from excessive use of generalized statements. To trace the delicate interconnexions betwoen taxonomy, phytogeography and ecology is no easy task; and somehow tho article fails to achiuve this aim. The arbitrary fragmentation of the subject into 'bits' does not help, and it is hard to see how 'types and typology' or 'herbarium problems' bear diroctly on the topic under reviow. At times a combative attitude obtrudes and there is some needless repetition. Much of the very sketchy chapter on "Floras" is self-evident and seems to be aimed at an entirely different class of reader from those visualized in the earlier contributions.

The final chapter on fossil plant taxonomy, by $\mathrm{Dr}$. K. I. M. Chesters, is a most readable summary of a wide range of palæobotanical work. It will be usoful to many non-specialist readers, but would have benefited greatly by illustrations on the liberal scale provided by Prof. Maheshwari.

The book is pleasantly produced, but botter proofreading would have eliminated numerous imperfections. Some are misprints, such as "micropore mother cells", "dabatable", "suported" and "phyllum" (phylum); others are examples of unfortunate phrasing such as "in the degree that" on p. 188, or confused construction where a sentence is loft with no main verb, as on pp. 271 and 277. One finds the use of "globulets" for globules, "millenni" for millennia (p. 199) and "petrification" for petrifaction (p. 261) annoying, but "climate vegetation" in place of climax vegetation (p. 198) and "rhizomorph" for rhizophore (p. 265) are more serious. "Subdividable" for divisible and "analogical" for analogous are further verbal atrocities which ought not to havo been allowed to mar a book of this class. With well under 300 pages of reading matter the book is a little expensive at five guineas.

E. V. WATson

\section{A WREATH FOR THE ENGLISH BOTANISTS}

Sertum Anglicum, 1788

By Charlos-Louis L'Héritier de Brutelle. Facsimile with Critical Studios and a Translation. (The Hunt Facsimile Series, No. 1.) Pp. xcviii $+36+34$ plates +12 . (Pittsburgh: The Hunt Botanical Library, Carnegie Institute of Technology, 1963.) n.p.

TO one, however charitable, ean honestly maintain 1 that Charles-Louis L'Héritier, Seigneur de Brutelle, has any particular claim to fame as a botanist. Ho was at most a competent disciplo of Linnaeus, content to elaborate and augmont the works of his master at a time when many of his more enlightened compatriots were following the banner of de Jussieu away from the rather sterile formalities of the sexual system.

L'Héritier's fow, and generally incomplete, publications are valued as rarities; they aro, for the most part, of grand dimensions and amply illustrated by exceptionally gifted artists; they also happen to contain the first published identifications, descriptions and figures of a number of plants, some of them now well known to others besides taxonomists. For these reasons a facsimile edition of tho raro (and incomplete) Sertum Anglicum is to be welcomed, indoed doubly wolcomed, because the Advisory 